\title{
RETTELE DE SOCIALIZARE - UN NOU CÂMP MISIONAR. O PERSPECTIVĂ CREȘTIN - ORTODOXĂ
}

Bogdan Gabriel STANA*

\begin{abstract}
Socialization networks - a new missionary field. A Christian perspective-orthodox ${ }^{1}$. The Internet contributes to revolutionary changes in trade, education, politics, journalism, and to relations between nations and between cultures, changes that are not just about the way that people communicate, but also how they conceive their lives. Also, the development of the technique has led to the emergence of new means of communication. Thus, given the growing access of people to smartphones and to the Internet, we can see that social networks are currently a powerful means of accessing information (some true, other not) and communicating. Analyzing only one of the 21 existing social networks (each with dozens and hundreds of branches or applications), namely Facebook, FaceBrands (Servicefor communications, analytics andstatistics about Facebook) transmitted through a press release that on the 10th January 2017 the figure of the Facebook user accounts, in Romania, was 9,6 million compared to 500 thousand on January, $1^{\text {st }}$, $2010^{2}$ from a population of around 19 million people ${ }^{3}$. A percentage of $50,52 \%$. If, at the beginning of the Christian era the Holy Apostles used all the technical means of their time, on the same model the servants of the Orthodox Church have the duty to use the latest means of
\end{abstract}

Priest, PhD Student, Faculty of Orthodox Teology at „1 Decembrie 1918” University, Alba Iulia, Romania.

${ }^{1}$ Studiu redactat sub îndrumarea pr. prof. univ. dr. habil. Mihai Himcinschi, care și-a exprimat acordul pentru publicare.

2 See press release of 10 January 2017 following the analysis made by FaceBrands, disponibil la http://www.facebrands.ro/demografice.html (accesat la 10.09.2019).

${ }^{3}$ National Institut of Statistics, Press release No. 212 of 29 august 2019, disponibil la http://www.insse.ro/cms/sites/default/files/com_presa/com_pdf/poprez_ian2019r.pdf (accesat la 10.09.2019). 
communication of time. This is because the proclamation of the Gospel, the teachings of faith, the elements of Catechism and the support of ecclesial promotions are a necessity and a duty according to the Holy Commandment that has travelled the millennia: „Therefore, learn all nations, by baptizing them in the name of the Father and the Son and the Holy Spirit (Mt. 28, 19)". Thus, we can speak about an adaptation in the sphere of communication that leads to communion, and not to the renunciation or betrayal of moral and spiritual values and teachings. This is why social networks can represent a missionary field and cultural factors that play an important role in the development of society at local, national, community and spiritual level in the light of the common good in a spirit of solidarity.

Keywords: Christian Orthodox Church, social networks, mission, communication, communion.

\section{Introducere}

Dezvoltarea tehnici a dus la apariția unor noi mijloace de comunicare, în cadrul cărora rețelele de socializare reprezintă o platformă din ce în ce mai solicitată. Accesul tot mai larg al oamenilor la telefoane inteligente și la internet a făcut ca în prezent rețelele de socializare să reprezinte mijlocul cel mai puternic de a avea acces la informație, de a comunica și chiar de a influența opinia publică ${ }^{4}$.

Dacă la începutul epocii creștine Sfinții Apostoli utilizau toate mijloacele tehnice ale timpului lor, pe același model, și noi avem datoria de a utiliza cele mai noi mijloace de comunicare ale timpului nostru. De aceea, folosirea acestora în vestirea Evangheliei, a învăţăturilor de credință, elementele de catehizare și sprijinirea promovărilor ecleziale reprezintă o necesitate a timpului nostru.

Conform comunicatului de presă redat de FaceBrands (serviciul comunicate, analize și statistici despre Facebook), în data de 10 ianuarie 2017, cifra conturilor de utilizatori de Facebook, în România, era de 9,6

${ }^{4}$ Eric Auchard, David IngRAm, Cambridge Analytica CEO claims influence on U.S. election, Facebook questioned, disponibil la https://www.reuters.com/article/usfacebook-cambridge-analytica/cambridge-analytica-ceo-claims-influence-on-u-selection-facebook-questioned-idUSKBN1GW1SG (accesat la 04. 12.2019). 
milioane față de 500 de mii la 1 ianuarie $2010^{5}$, dintr-o populaţie de aproximativ 19 milioane de oameni rămaşi în România, conform comunicatului de presă al Institutului Național de Statistică ${ }^{6}$. Un procent de 50,52\%, numai în Muntenia existând 3.426.240 conturi de Facebook.

Din realitatea practică cu care ne confruntăm fiecare în ceea ce privește participarea efectivă a oamenilor la sfintele slujbe săvârșite în Sfânta Biserică, se poate constata că procentul mediu, pe an, al acestora este inferior celui care transmite prezența oamenilor în spațiul online, pe rețelele de socializare. Astfel, prezența slujitorilor Bisericii și a exercitării misiunii de propovăduire a mesajului evanghelic și în spaţiul online devin din ce în ce mai necesare.

\section{Necesitatea prezenței mesajului Bisericii pe rețelele de socializare}

Societatea românească este într-o continuă schimbare, în mod intens, începând cu anii 1991-1992, de când i-a fost prezentată și însușită ideea globalizării - spaţiu în care identitatea națională și religioasă, gândul și opinia sunt sub amenințare. Astfel, în anul 2005, profesorul Tiberiu Brăileanu, în cartea Globalizarea. Numele nimicului, afirma: „Globalizarea este un fenomen confuz și atât de complex, indefinibil în totalitatea lui" "7. Anthony Giddens, în anul 2010, 1-a completat, având în vedere implicațiile sociale ale procesului globalizării, subliniind:

„Globalizarea schimbă fundamental natura experiențelor noastre cotidiene. Aceasta îndeamnă la redefinirea aspectelor sociale personale și intime ale vieții noastre, precum familia, rolurile de gen, sexualitatea, identitatea personală, interacțiunile noastre cu ceilalți și relațiile de muncă. Modalitatea în care gândim despre noi înșine și legăturile noastre cu ceilalți sunt profund modificate de globalizare" 8 .

Așadar, acestea sunt câteva dintre aspectele care să ne determine să credem că platforma discuțiilor, dezbaterilor dintre oameni, fie că este în conformitate cu convingerile noastre sau nu, s-a mutat în spaţiul virtual

${ }^{5}$ FaceBrands, comunicat cit.

${ }^{6}$ Institutul Național de Statistică, comunicat cit.

7 Tiberiu BrắlLEAnU, Globalizarea. Numele nimicului, Iaşi, Edit. Institutul European, 2005, p. 130.

${ }^{8}$ Anthony Giddens, Sociologie, București, Edit. ALL, 2010, p. 64. 
și, în mod special, pe rețelele de socializare, unde informaţia este transmisă rapid și fără inhibiții. Toate acestea descriu ceea ce nu mai este o noutate, faptul că epoca noastră poartă printre alte nume și acela de ,eră a comunicării virtuale"9 . Se conturează, din ce în ce mai proeminent, generației Web, tulburările în organizarea timpului și spațiului, în modul de informare și comunicare, consecințele ecleziologice, efectele asupra guvernării Bisericii, a locului religiei pe piața de internet, a modalităţilor și mijloacelor de proclamare a mesajului Evangheliei.

Internetul se transformă; transformă societatea și nu poate să nu transforme modul de a fi, de a acționa în Sfânta Biserică și în lucrarea misionară prin care se transmite „Calea, Adevărul și Viața” (In. 14, 6). Asistăm la o revoluție copernicană care ne afectează deja modul de a fi în relația noastră cu lumea, de a fi în lume, de a interacționa cu lumea. Sub acest aspect se poate afirma că importanța internetului este conștientizată de către Biserică, după cum menționa Preafericitul Părinte Daniel, Patriarhul Bisericii Ortodoxe Române: „Intrenetul, rețelele de socializare pot contribui la o mai bună cunoaștere reciprocă a diferitelor tradiții și la consolidarea comunităților de credință" ${ }^{\prime \prime}$.

Internetul este revelator, un marker. Fie știi să comunici, fie nu știi, ești credibil sau nu ești, ori faci față așteptărilor sau te afli sub carapacea ta, ori ești profet sau ultimul dintre mohicani, fie ești viu, fie ești fosilă, fie știi limbajul internetului sau nu îl știi, și deci nu poți comunica. Astfel, asemenea unui misionar care pleacă într-o țară străină pentru a propovădui învățătura, un misionar căruia i se cere să învețe limba și cultura țării respective, tot aşa Biserica are datoria de a înțelege „modul de funcționare al societății informaționale din zilele noastre spre a comunica valorile Ortodoxiei" ${ }^{11}$. Astfel, prin utilizarea internetului și a rețelelor de socializare Biserica are posibilitatea majoră a întâlnirii adolescenților și tinerilor de astăzi deoarece ei ,,sunt utilizatorii importanţi ai noilor instrumente, fie că sunt telefoane

${ }^{9}$ Horea Mihai BăDĂU, Tehnici de comunicare în Social Media, Iași, Edit. Polirom, 2011, p. 16.

10 Patriarhul DANIEL, Utilizarea rețelelor de socializare și a internetului, disponibil la https://basilica.ro/patriarhul-daniel-despre-utilizarea-retelelor-de-socializare-si-ainternetului/ (accesat la 18.12.2019).

${ }^{11}$ Ibidem. 
mobile sau alte instrumente care oferă posibilitatea de a avea acces la internet cu un singur click" 12 . De aceea pe internet devine evidentă crearea unor limbaje noi, folosite de tineri. Abrevieri, fotografii și emoticoane, fișiere audio și videoclipuri sunt tot mai preponderente. Cultura digitală este înzestrată cu propria gramatică, o limbă în continuă și rapidă evoluție.

„Generațiile mai înaintate în vârstă au o tendință prea mare să considere superficial tot ceea ce este scurt, instantaneu, concentrat pe emoție. Poate pentru că sunt mai orientate către cuvântul scris, către evoluțiile îndelungate, către calitatea argumentării prin fișierele groase cărora trebuie să le facem față" ${ }^{\prime \prime}$.

Astfel, având în vedere că de-a lungul istoriei Biserica a putut săşi exprime credința nu numai prin tratatele lungi de teologie, ci și concis, este evidențiată și necesară preocuparea ei de a comunica cu oamenii de astăzi aflaţi în agora modernității, dominată de tehnologie. Astfel, este suficient să ne gândim la icoane, la frescele și mozaicurile bisericilor noastre; n doar emoții, ci și comunicare simplă, eficientă și concisă. Și la fel se întâmplă în muzica Bisericii, în textele ei liturgice.

Proclamăm „o singură credință, un singur botez, un singur Dumnezeu" (Efes. 4, 5), dar există multe modalități de a exprima această credinţă. În acest sens, încă de la Sfântul Apostol Pavel care spunea: ,„... tuturor toate m-am făcut, ca, în orice chip, să mântuiesc pe unii." (I Cor. 9,22), Biserica îndeamnă să actualizăm constant modul în care propunem credința noilor generații.

De asemenea, Mântuitorul Iisus Hristos ne-a lăsat o poruncă sfântă ce a străbătut mileniile: „Drept aceea, mergând, învățați toate neamurile botezându-le în numele Tatălui și al Fiului și al Sfântului Duh,/ învățându-le să păzească toate câte v-am poruncit vouă, și iată Eu cu voi sunt în toate zilele, până la sfârșitul veacului. Amin” (Mt. 28, 19-20). Astfel, trimite spre misiune. O misiune care este descrisă ca fiind „,forma vizibilă a iubirii Sfintei Treimi faţă de om, actualizată în cel mai eficient

12 Andreea-Monica STATE, „Adolescenții și dependența de Internet”, în Sinteza, București, Edit. Universitatea București, nr. 21, 2015, p. 2.

${ }^{13}$ Constantin CuCIUC, „Diversificarea cercetărilor de sociologia religiilor”, în Sociologia Românească, București, anul III, nr. 6/1992, p. 614. 
mod de Iisus Hristos şi lăsată ca moştenire Bisericii Sale, pentru mântuirea omului"'14.

Totodată, în Evanghelia după Marcu, Hristos îndeamnă: „Mergeţi în toată lumea şi propovăduiţi Evanghelia la toată făptura; cel ce va crede şi se va boteza se va mântui, iar cel ce nu va crede, se va osândi" (Mc. 16, 15-16). Din cele doua texte enunțate, prin cuvintele „toate neamurile” și „toată lumea”, înțelegem că aici sunt cuprinși toți oamenii. Toți sunt responsabilitatea noastră pentru că misiunea, apostolatul sau trimiterea spre lume, evocă dinamica Bisericii lui Iisus Hristos, care nu este un organism static, reflectând un anume stadiu din istorie, ci un organism viu, care se adaptează la condiţiile de viaţă, urmărind în permanenţă slujirea Mântuitorului.

Aflându-ne într-o astfel de lume, în care internetul poate facilita comunicarea și accesul la informație, Biserica nu poate ignora această realitate. Ea „nu poate comunica într-o manieră ca și cum alte concepții și interpretări ale lumii nu ar exista"15. Are un Cuvânt, un mesaj de dragoste de proclamat ce presupune, implicit, ascultarea, iar internetul este o cameră minunată de ecou a vieții lumii. Însă, în procesul de misiune şi evanghelizare în lumea digitală, mesajul Bisericii ar trebui să fie diversificat sau adaptat dupa vârsta și preocupările oamenilor încât să fie evitat un discur monopolit ${ }^{16}$. De aceea, înainte de orice postare, este indicat să fie evaluat modul în care această sau acea imgine, acest sau acel comentariu pot fi auzite, raportate sau interpretate. Având în vedere acest aspect și contextul, „mesajul transmis presupune o analiză sporită, încât e nevoie de spontaneitate și receptivitate pentru că Web-ul începe a se defini ca o cultură a spontanului" ${ }^{17}$.

În istoria Bisericii, în timp ce filantropia era inventivă pentru a răspunde noilor nevoi, vechile structuri au fost, într-o oarecare măsură, depășite. Astăzi, într-un asemenea context social, în care o bună perioadă

${ }^{14}$ Dan SANDU, „Teologia și practica misiunii în Biserică azi. O tratare comparativă”, în Analele științifice ale Universității «Alexandru Ioan Cuza», Iași, Edit. Universității, 2003, p. 47.

15 Laurențiu TĂNASE, Religia și media-logica concurenței religioase, București, Edit. Universitatăţii din București, 2010, p. 34.

${ }^{16}$ Ibidem.

${ }^{17}$ Bernard Dagenais, Les médias ont imposé une nouvelle logique à la religion, Franța, Edit. Presses Universitaires de Bordeaux, 1996, p. 21. 
de timp din viața oamenilor se desfăşoară în spațiul online sau pe rețelele de socializare, nevoia prezenței Bisericii pe YouTube, MySpace, Facebook etc. devine din ce în ce mai sporită. Aceasta pentru că oamenii nu trebuie să piardă din vedere conștiința, darul și responsabilitatea prezenței chipului lui Dumnezeu în ei, precum și calea spre asemănarea cu El în virtute. Prezenţa Bisericii pe rețelele de socializare nu reprezintă un moft, ci o necesitate pentru informarea corectă și comunicare, ce pot conduce, mai devreme sau mai târziu, spre comuniune. Totodată, ea nu este o invitaţie la ,virtualizarea" religiei prin traducerea tehnică a îndemnului Mântuitorului, „când doi sau trei sunt conectaţi în numele Meu...", ci tocmai o cale de a încuraja redescoperirea nemijlocită a vieţii comunitare fizice. În ciuda diferenţei de suport, mesajul se supune din punct de vedere religios rigorilor aceleiaşi hermeneutici, motiv de a vedea în internet sau în rețelele de socializare nu mai mult decât ceea ce sunt, adică de a nu ceda formulei lui McLuhan „mediul este mesajul”18.

Navigând pe internet, pe orice rețea de socializare precum Facebook, realizăm nevoia de a comunica, nevoia unei întâlniri și a unui dialog autentic. Autenticitatea pentru tânăra generație, în special, este un semn de adevăr. Prin urmare, trebuie promovată o prezență creștină pe web, formată din operatori, preoți inclusiv, care să stăpânească tehnicile de comunicare prin care să se creeze spații pentru cercetare, întâlnire, dialog, rugăciune.

Doar ascultarea lumii, pe de o parte, și ascultarea de Dumnezeu, pe de altă parte, pot permite poziționarea Bisericii, acolo unde nu este aşteptată, să surprindă, să dărâme concepțiile greșite. Având în vedere că rețelele de socializare şi internetul, în integritatea lui, devine din ce în ce mai mult o parte integrantă a vieții de zi cu zi, nefiind prezenți, se naște, automat, o îndepărtare de ceea ce se întâmplă în viața oamenilor.

Abordarea rețelelor de socializare ca un câmp deschis pentru misiune oferă şi ea Bisericii posibilitatea să trezească conștiințe, oferă posibilitatea să poarte de grijă lumii fără să se despartă de vreo parte a acesteia. Însă, pentru realizarea acestui lucru, este indicat să se evite „limbajul de lemn, să se evite propunerea vreunei ideologii care caută să-

18 Marshall Mcluhan, Understanding Media. The extension of man, New York, Edit. Taylor \& Francis Ltd, 2001, p. 7. 
și impună adevărul cu orice preț"19. Dealtfel, este cerută prezenţa dialogului și a dezbaterii, arătând în același timp că nu vor fi compromise anumite principii acceptate de toți și de pretutindeni. De aceea, mulţumirea incipientă vine doar din propunerea adevărului Mântuitorului Hristos, într-un mod ferm, tandru, cu smerenie. Și dacă este vorba de a da socoteală despre speranța care este în noi celor care o solicită, să fie „,cu blândețe și îngăduință” (Tit 3, 2), spune Sfântul Apostol Pavel.

Prezența Bisericii pe rețelele de socializare dovedește încă o dată faptul că nu se creează ziduri între Biserică și lume, pentru că Mântuitorul Hristos nu face o astfel de distincție, sau, mai degrabă, distincția este alta, ea trece prin hotarul inimii noastre: „Cine nu este împotriva noastră, este pentru noi” (Mc. 9, 40), spunea El Sfinților Apostoli. Această realitate evidențiată de Hristos invită spre extinderea spațiului misionar.

O diferențiere accentuată între media profană și media eclezială poate da naștere riscului de victimizare, fără a auzi ce are de spus lumea despre Biserică, fără a înțelege cum o simte, fără să încerce să afle cum poate fi prezentă în toată mass-media.

Internetul este și rămâne un instrument care poate dobândi şi laturi imorale. Poate fi utilizat de oameni capabili să facă binele și răul. Ca orice instrument care înmulțește capacitățile umane, are potențial să facă bine, dar poate deveni și amenințător. Totul depinde de cum îl utilizăm. Moralizarea internetului nu se va întâmpla fără moralizarea oamenilor. De aceea, nevoia prezenței Bisericii pe rețelele de socializare este mai mare, pentru că nu are în vedere doar aspectul extensive al mesajului Evanghelieim ci şi aspectul moralizant, calitativ al mesajelor de pe internet. Mesajul virtual „on line” al Bisericii se poate coagula ca un catalizator al cuvintelor care circulă în lumea internetului, transformândule în cuvinte vii, frumoase. La fel cum crucea este și verticală și orizontală, la fel trebuie să fie şi evanghelizarea noastră: orizontală prin întinderea sa și verticală prin adâncimea și calitatea sa.

\section{Concluzii}

Astfel, fără să fie desființate vizitele parohiale sau Sfânta Liturghie să fie săvârşită în altă parte decât Sfântul Altar, fără să acceptăm

${ }^{19}$ Laurențiu TĂNASE, Religia și media-logica concurenței religioase, p. 36. 
săvârşirea Sfintei Taine a Spovedaniei în mediul online, este nevoie ca Biserica să fie prezentă ca un stâlp al adevărului, al moralității și al informării corecte pe rețelele de socializare ce reprezintă, cu siguranță, un câmp misionar. Fără să reprezinte aşadar o alternativă la comunitatea de credinţă, rețelele de socializare pot fi, totuşi, un liant şi, de ce nu, o formă nouă de practicare a „liturghiei de după Liturghie”, un spaţiu al mărturiei şi al diaconiei sociale. Biserica este mai solicitată misionar decât oricând. Este provocată de contextul nou la care trebuie să răspundă pertinent şi punctual. Noi ştim că Mântuitorul Hristos conduce Biserica la tot adevărul, dar şi că slujitorii trebuie să-i înţeleagă rostul şi misiunea, să o slujească în a-şi împlini vocaţia eshatologică prin transmiterea cu mijloace adecvate a Adevărului. Pastoraţia în mediul virtual este aşadar complementară celei clasice, față către față, comunicarea la distanță nefiind un substituit al celei concrete.

\section{Referinţe bibliografice:}

1. BĂDĂU, Horia Mihai, Tehnici de comunicare în Social Media, Iași, Edit. Polirom, 2011;

2. BRĂILEANU, Tiberiu, Globalizarea. Numele nimicului, Iași, Edit. Institutul European, 2005;

3. CUCIUC, Constantin, „Diversificarea cercetărilor de sociologia religiilor”, în Sociologia Românească, București, anul III, nr. 6, 1992, p. 611-623;

4. DAgENAIS, Bernard, Les médias ont imposé une nouvelle logique à la religion, Franța, Edit. Presses Universitaires de Bordeaux, 1996;

5. GIDDENS, Anthony, Sociologie, București, Edit. ALL, 2010;

6. MCLUhan, Marshall, Understanding Media. The extension of man, New York, Edit. Taylor \& Francis Ltd, 2001;

7. STATE, Andreea-Monica, „Adolescenții și dependența de Internet”, în Sinteza, București, Edit. Universităţii din București, nr. 21, 2015, p. 2-7;

8. TĂNASE, Laurențiu, Religia și media-logica concurenței religioase, București, Edit. Universităţii din București, 2010;

9. SANDU, Dan, „Teologia și practica misiunii în Biserică azi. O tratare comparativă”, în Analele științifice ale Universității«Alexandru Ioan Cuza», Iași, Edit. Universității, 2003, p. 39-51;

10. AuCHARD, Eric, Ingram, David, Cambridge Analytica CEO claims 
influence on U.S. election, Facebook questioned https://www.reuters.com/article/us-facebook-cambridge-

analytica/cambridge-analytica-ceo-claims-influence-on-u-s-electionfacebook-questioned-idUSKBN1GW1SG:

11. FACEBRANDS: Date demografice Facebook România din 10 ianuarie 2017 disponibil pe http://www.facebrands.ro/demografice.html;

12. Patriarhul DANIEL, Utilizarea rețelelor de socializare și a internetului https://basilica.ro/patriarhul-daniel-despre-utilizarea-retelelor-desocializare-si-a-internetului/;

13. InSTITUTUl NAȚIONAL de STATISTICĂ: Populația stabilă (rezidentă) structura demografică, vol. 1, nr.1, 2011 disponibil la http://www.recensamantromania.ro/noutati/volumul/. 